DOI: $10.18698 / 0236-3933-2018-3-83-90$

\title{
ON THE FORMULATION OF THE PROBLEM OF OPTIMAL CONTROL OF PRODUCTION PARAMETERS USING A TWO-LEVEL MODEL OF THE PRODUCTION PROCESS
}

\author{
O.M. Pihnastyi \\ O.O. Parachnevych
}

\author{
pihnastyi@gmail.com \\ paraoksana1@gmail.com
}

\begin{abstract}
National Technical University "Kharkiv Polytechnic Institute", Kharkiv, Ukraine
\end{abstract}
\begin{abstract}
Using a statistical approach, widespread in natural sciences, a two-level model to control the parameters of the flow line production system has been built. The state of the system is given by the amounts of sets of the objects of labour. The state of the subject of labour is given by a point in the phase space. The function of distribution of objects of labour by state is introduced and the kinetic equation for the distribution function is written. Now we have closed system of dynamical equations for parameters of flow production line. The null and the first moments of the distribution function of labor objects in terms of the state characterize the magnitude of interoperational stocks and the rate of processing of labor objects from operations of the technological route and are the main parameters of the management of the production line. The limiting transition from the kinetic description of the state of objects of labor to the stream description of the processing of objects of labor is accomplished. Integration of the kinetic equation by the states of the objects of labor made it possible to construct a closed system of balance equations for the parameters of the production line. The task of optimal control of the flow parameters of the production line has been set. The balance equations for the moments of the distribution function of objects of labor by states determine the constraint equations in the control problem
\end{abstract}

Received 18.12.2017

(C) BMSTU, 2018

\section{Keywords}

Stability of mass production processes functioning, production systems, flow production line, enterprise, business process, basic product, technological chain, BP distribution function

Statement of the problem and analysis of publications. The modern enterprise is on the one hand a complex production and technical system and on the other hand a complex economic [1] system that interacts with the external environment $[2,3]$. The diversity and complexity manufacturing technology of the product creates prerequisites for modeling the internal environment of a production enterprise on the basis of the concept of a production system as a set of objects of labour that are in different stages of technological processing [4-7]. However, to monitor the behavior of a single object of labour in the production process, because of its very large number and probabilistic nature of the impact on the subject of labour of the production and technical environment through technological equipment is practically impossible $[2,5,6,8]$. 
An effective approach to modeling such complex production and technical and economic large systems is a statistical approach $[1,10]$ that considers the enterprise's production process at two levels of description - a microlevel, that considers production and technical aspects, and a macrolevel, that considers the economic aspects of the enterprise's production process. At the microlevel, the patterns of behavior of individual elements-objects of labor, based on a given production technology, are investigated [4]. At the macrolevel - their aggregated economic characteristics, the relationships between these characteristics and the external environment through the investment mechanism are studying [3]. The interrelation between the levels is realized through the kinetic equation, describing the evolution of the state change of the elements of large systems in the phase space under consideration $[10,11]$. Features of the application of the statistical approach to the modeling of such systems are discussed in this article.

Purpose of the article. The substantiation of the theoretical foundations of the statistical description of production and economic systems with the flow method of production organization for constructing algorithms for optimal management of production parameters.

Model of microlevel. Descriptions of the enterprise as a complex production technical and technical system. During the execution of the technological operation on the object of labour transfers the value of technological resources through the directed influence of technological equipment $[9,12]$. At each operation, inevitably there are fluctuations in production and technological characteristics, describing the state of objects of labour. The change in the state of labor objects occurs as a result of the transfer of production factors $[12,13]$ - energy resources, labor, raw materials, materials and semi-finished products to labor. At the same time, random and systemic deviations of the actual value of the parameter of the produced products from its nominal value established by the normative and technical documentation [GOST 15895-77] occur at each technological operation (in Russian).

Thus, the technological process is a random process of transfer of objects of labour from one state to another because of the influence of the internal environment of the production and technical system on the subject of labour through technological equipment [10]. The state of the internal environment of the production and technical system is defined as the state $N$ numbers of objects of labour $[10,11]$. The state of the subject of labour at time $t$ can be represented by coordinates in the $S_{j}$ phase space $(t, S, \mu)[9,10-12]$. The state of the individual subject of labor will be characterized by the sum of the resource costs $S_{j}(\$)$, and the intensity of resource transfer per unit time $\mu_{j}(\$ / \mathrm{h})$ from technological equipment to the $j$-th subject of labour, $0<j<N$. The coordinates $S_{j}, \mu_{j}$ determinate the technological trajectories of objects of labour in the phase space $S_{j}=S_{j}(t)$. The intensity $\mu$ of the transfer of resources $\Delta S=\Delta S(t)$ from the means of labour to the $j$-th subject of labour during the execution of the technological operation for the time $\Delta t$ is the random process [11-13], the value of which at a fixed time is determined by the random variable: 


$$
\mu=\frac{\Delta S}{\Delta t} .
$$

The state of the production and technical system at some point in time will be determined if the production and technical parameters $S_{j}$ and $\mu_{j}$ are determined, and at any other time is found from the equations of state for the production and technical parameters of the object of labour [14]:

$$
\frac{d S_{j}}{d t}=\mu_{j}, \frac{d \mu_{j}}{d t}=f_{j}\left(t, S_{j}\right),
$$

$f_{j}\left(t, S_{j}\right)$ - production function of the technological equipment of the production and technical system. If the number of objects of labour is much greater than one, then it is practically impossible to solve system (1) from $2 \mathrm{~N}$-equations. Instead of considering the state of the objects of labour of the technological process of the production and technical system with the parameters $S_{j}$ and $\mu_{j}$, we introduce the normalized function of the distribution of objects of labour according to the states. Each point in a given space will define the state of the object of labour. It is reasonable to expect that for large $N$ this function will well approximate the continuous distribution function of objects of labor according to the states $\chi(t, S, \mu)$ [11].

Relation of models of microlevel and macrolevel of the description of the production enterprise as a complex system. Kinetic equation of the production line. We divide the phase space by such a number of cells that the cell dimensions $\Delta \Omega=\Delta S \Delta \mu$ were much smaller than the values of the characteristic parameters of the production and technical system and at the same time contained inside themselves a large number of objects of labour.

For enterprises with a flow-based method of organizing production, the fact that in the inter-operational department before the technological operation contains a large number of objects of labor is characteristic. This allows the technological route to be divided into production sections with the length $\Delta S_{m}=S_{m}-S_{m-1}$, each of which contains several or one separate technological operation. Each section $\Delta S_{m}$ contains technological equipment and an inter-operative store, in which a line of a large number of objects of labor is formed. If a very large number of objects of labor is contained within the technological operation, the section $\Delta S_{m}$ can be divided into additional sections in accordance with how the technological operation can be divided into elements (manufacturing step, position, manufacturing pas, auxiliary pass, setting-up) according to GOST 3.1109-82 (in Russian).

Instead of fixing the exact values of the production and technical parameters of the objects of labour, we will approximately characterize the state of the production and technical system by the number of objects of labour in each cell $\Delta \Omega$. If the cell size is sufficiently small, then an approximate description will carry in itself almost as detailed information as the exact one. Since the quantity $\chi(t, S, \mu) d \Omega$ represents the number of objects of labor in an infinitesimal cell $\Delta \Omega$ of the phase space, we can judge from the change in the phase coordinate $S$ and the phase velocity $\mu$, and also about the change in the function $\chi(t, S, \mu)$ itself $[11,15]$ : 


$$
\begin{gathered}
\frac{\partial \chi(t, S, \mu)}{\partial t}+\frac{\partial \chi(t, S, \mu)}{\partial S} \mu+\frac{\partial \chi(t, S, \mu)}{\partial \mu} f(S)=J(t, S, \mu) ; \\
\frac{d S}{d t}=\mu ; \frac{d \mu}{d t}=f(S) .
\end{gathered}
$$

Equation (2) describes the change in the phase space $\Delta \Omega$ averaged over an infinitesimal cell of the production and technical characteristics of the objects of labour $S_{j}, \mu_{j}$. We shall assume that the function $\chi(t, S, \mu)$ is normalized

$$
\int_{0}^{\infty} d S \int_{0}^{\infty} d \mu \chi(t, S, \mu)=N
$$

The production function $f(t, S)$ is determined from the given mode of production [16]. When moving along the technological route for the subject of labour, there is an impact on the part of the internal production and technical environment of the enterprise by means of technological equipment located with a density $\lambda(S)$. We can only talk about the probability that after such exposure to the working environment will be the subject of work in a particular state. This probabilistic nature of the impact can be taken into account by specifying a function $\psi(t, S, \mu)$ that determines the probability that after the impact the object of labor will consume technological resources with intensity $\mu$. The function $\psi(t, S, \mu)$ can be set by analyzing the passport data of the process equipment [17]:

$$
\int_{0}^{\infty} \psi(t, S, \mu) d \mu=1, \int_{0}^{\infty} \mu^{k} \psi(t, S, \mu) d \mu=[\psi]_{k}, \quad k=1,2, \ldots
$$

The number of objects of labour that have experienced, per unit time, the impact from the internal production and technical system through the technological equipment in the cell $d S d \mu$ with coordinates $(S, \mu)$ and moved as a result of the action in the cell $d S d \tilde{\mu}$ with coordinates $(S, \tilde{\mu})$ is proportional to the product of the flow of labour objects $\chi(t, S, \mu) \mu$ to the probability of transition $\psi(t, S, \mu)$. The number of objects of labour that experienced an impact on the part of the internal production and technical system per unit of time and assumed values within $(\tilde{\mu} ; \tilde{\mu}+d \tilde{\mu})$ is a quantity $\psi(\tilde{\mu}) \lambda(S) \mu \chi(t, S, \mu) d \tilde{\mu} d S d \mu$. Along with this, the volume $d S d \mu$ element receives objects of labour from volume $d S d \tilde{\mu}$ by the reverse transition in quantity $\psi(\mu) \lambda(S) \tilde{\mu} \chi(t, S, \tilde{\mu}) d \tilde{\mu} d S d \mu$, and the total number of objects of labour in the volume $d S d \mu$ element changes per unit time by the amount $d S d \mu J$ [15]:

$$
J=\lambda(S) \int_{0}^{\infty}\{\psi(\mu) \tilde{\mu} \chi(t, S, \tilde{\mu})-\psi(\tilde{\mu}) \mu \chi(t, S, \mu)\} d \tilde{\mu} .
$$

From where the kinetic equation (3) can be represented in the form:

$$
\frac{\partial \chi(t, S, \mu)}{\partial t}+\frac{\partial \chi(t, S, \mu)}{\partial S} \mu+\frac{\partial \chi(t, S, \mu)}{\partial \mu} f=\lambda\left\{\int_{0}^{\infty} \psi(\mu) \tilde{\mu} \chi(t, S, \tilde{\mu}) d \tilde{\mu}-\mu \chi(t, S, \mu)\right\} .
$$


In most practical cases, the function $\psi(t, S, \mu)$ does not depend on the state of the objects of labor until the impact from the internal production and technical system is tested, from where

$$
\frac{\partial \chi(t, S, \mu)}{\partial t}+\frac{\partial \chi(t, S, \mu)}{\partial S} \mu+\frac{\partial \chi(t, S, \mu)}{\partial \mu} f=\lambda(S)\left\{\psi(\mu)[\chi]_{1}-\mu \chi\right\} .
$$

The solution of equation (3) provides the ability to calculate the values of the macroparameters is associated with great difficulties $[9,11]$.

Macrolevel model. Macromodel of the production line description. The state of the technological process at the macrolevel will be described by the moments of the distribution function of the objects of labour over the states $\chi(t, S, \mu)[17]$ :

$$
\int_{0}^{\infty} \mu^{k} \chi(t, S, \mu) d \mu=[\chi]_{k}, \quad k=0,1,2, \ldots
$$

which are aggregated stream parameters of the production line. It is known $[9,10$, $18]$, that the first moments of the distribution function are used to describe the state of large systems of systems on a macrolevel (4). Multiplying Eq. (3) by $\mu^{k}$, $k=0,1,2, \ldots$ and integrating over the entire range $\mu$, we obtain non closed equations of the balance of the state of the flow parameters of the production line:

$$
\begin{gathered}
\frac{\partial[\chi]_{0}}{\partial t}+\frac{\partial[\chi]_{1}}{\partial S}=\int_{0}^{\infty} d \mu J \\
\frac{\partial[\chi]_{k}}{\partial t}+\frac{\partial[\chi]_{k+1}}{\partial S}=k f(t, S)[\chi]_{k-1}+\int_{0}^{\infty} d \mu \mu^{k} J, \quad k=1,2,3, \ldots
\end{gathered}
$$

If the average amount of technological resources $\langle\Delta S\rangle$ transferred during the performance of a technological operation for an object of labour is much less, than the cost of the final product $S_{d}$, which is characteristic of a technological process consisting of a large number of technological operations, balance equations (5) in the zeroth approximation in the small parameter $\langle\Delta S\rangle / S_{d} \ll 1$ will take the form:

$$
\begin{gathered}
\frac{\partial[\chi]_{0}}{\partial t}+\frac{\partial[\chi]_{1}}{\partial S}=0, \quad \frac{[\chi]_{k}}{[\chi]_{1}}=[\psi]_{k-1}, \\
\frac{\partial[\chi]_{k}}{\partial t}+\frac{\partial[\chi]_{k+1}}{\partial S}=k f(t, S)[\chi]_{k-1}, \quad k=1,2,3, \ldots
\end{gathered}
$$

The system of balance equations (6) is closed, represents a balance relationship between the parameters of the enterprise macroparameters.

Formulating the problem of optimal control of the flow parameters of the production line. In a general form, the problem of determining the optimal program [6] for managing the flow parameters of a manufacturing enterprise $[\chi]_{0}(t, S),[\chi]_{1}(t, S)$ can be formulated as follows.

Determine the state of the parameters $[\chi]_{0}(t, S) \in G_{0}, \quad[\chi]_{1}(t, S) \in G_{1}$ flow technological line during the period $t \in\left[0, T_{d}\right]$ along the technological route $S \in\left[0, S_{d}\right]$ 
when managing the flow parameters of the production line $U_{\delta}(t, S)=W_{\delta}(t, S) \in G_{U}$ that deliver a minimum to the functional (objective function) [19]:

$$
C=\int_{0}^{T_{d}} \int_{0}^{S_{d}} U_{\delta}(t, S) \omega_{z}(t, S) d S d t \rightarrow \min , \quad(\$),
$$

for differential connections (6)

$$
\frac{\partial[\chi]_{0}(t, S)}{\partial t}+\frac{\partial[\chi]_{1 q}(S)}{\partial S}=-\frac{\partial\left([\chi]_{1 q}(S) U_{\delta}(t, S)\right)}{\partial S},
$$

constraints along the trajectory to the phase variables $[\chi]_{0}(t, S)[6]$

$$
0 \leq[\chi]_{0}(t, S), \quad[\chi]_{0}(t, S) \leq[\chi]_{0 G}(S),
$$

restrictions along the trajectory to control [6]

$$
0 \leq U_{\delta}(t, S), \quad U_{\delta}(t, S) \leq U_{\delta G}(S),
$$

under the initial conditions

$$
[\chi]_{0}(0, S)=[\chi]_{00}(S)
$$

in the final state (control objective)

$$
[\chi]_{0}\left(T_{d}, S\right)=[\chi]_{0 T_{d}}(S),
$$

and boundary conditions

$$
[\chi]_{1}(t, 0)=[\chi]_{1 q}(0) ;[\chi]_{1}\left(t, S_{d}\right)=[\chi]_{1 q}\left(S_{d}\right) .
$$

The objective function (7) determines the quality criterion for controlling the flow parameters of the technological process of the production enterprise during the production cycle $T_{d}$ for the whole technological route $\left[0, S_{d}\right]$.

Conclusions. At first glance, it would be possible to conclude that with the increase in the number of elements, the complexity of the system under consideration is unimaginably increased and there is no trace of any regularity in its behavior. The study of systems consisting of a very large number of subjects of labour in the technological process made it possible to reveal an important principal feature of such systems. It consists in the fact that the behavior of such systems is determined by regularities of a particular type, which have received the names of statistical regularities. The importance of applying the statistical approach is in constructing the highly effective management for the flow production lines, it provides a "simplified mechanism" for describing the macroscopic characteristics of systems. In many cases of practical interest, such a description is quite sufficient.

The article substantiates the theoretical foundations of the statistical description of production systems and presents the concept of constructing a model of the flow production, which consists of presenting the system at two levels. At the first level of description, the movement of the object of labor along the technological route is simulated. This allows taking into account the peculiarities of manufacturing the product according to the normative production technology [14]. 
The second, macrolevel of the description makes it possible to determine the relationships between the flow macroparameters of the production system: the interoperational backlog $[\chi]_{0}(t, S)$ and the rate of processing of labor items $[\chi]_{1}(t, S)$ on each technological operation. The relationship between these parameters is constructed taking into account the specific technological route of production of the product. The relationship between the levels of description is presented through the kinetic equation of the production process [11].

The obtained results are of theoretical and practical interest in the design of control systems for parameters of the flow line in the mining industry [20], for enterprises producing semiconductor products [21], automotive industry, rolling production.

\section{REFERENCES}

[1] Letenko V.A., Rodionov B.N. Organizatsiya, planirovanie i upravlenie mashinostroitel'nym predpriyatiem. Vnutrizavodskoe planirovanie. Ch. 2 [Organization, planning and management of a machine-building enterprise. Intrafactory planning]. Moscow, Vysshaya shkola Publ., 1979. 232 p.

[2] Kempf K.G. Simulating semiconductor manufacturing systems: successes, failures and deep questions. Proc. 1996 Winter Simulation Conf. Institute of Electrical and Electronics Engineers, 1996, pp. 3-11.

[3] Forrester J. Industrial dynamics. Wiley, 1961. 464 p.

[4] Glushkov V.M., ed. Planirovanie diskretnogo proizvodstva v usloviyakh ASU [Planning of discrete production in the conditions of ACS]. Kiev, Tekhnika Publ., 1975. 296 p.

[5] Petrov B.N., Ulanov G.M., Gol'denblat I.I., Ul'yanov S.V. Teorii modeley v protsessakh upravleniya (Informatsionnyy i termodinamicheski aspekty) [Theories of models in management processes (Informational and thermodynamic aspects)]. Moscow, Nauka Publ., 1978. 224 p.

[6] Pervozvanskiy A.A. Matematicheskie metody v upravlenii proizvodstvom [Mathematical methods in production management]. Moscow, Nauka Publ., 1975. 616 p.

[7] Balashevich V.A. Matematicheskie metody v upravlenii proizvodstvom [Mathematical methods in production management]. Minsk, Vysshaya shkola Publ., 1976. 334 p.

[8] Prytkin B.V. Tekhniko-ekonomicheskiy analiz proizvodstva [Technical and economic production analysis]. Moscow, Yuniti Publ., 2000. 399 p.

[9] Pignastyi O.M. Statisticheskaya teoriya proizvodstvennykh sistem [Statistical theory of production systems]. Kharkiv, KhNU Publ., 2007. 388 p.

[10] Vlasov V.A., Tikhomirov I.A., Loktev I.I. Modelirovanie tekhnologicheskikh protsessov izgotovleniya promyshlennoy produktsii [Technological processes modeling of industrial products manufacturing]. Tomsk, TPU Publ., 2006. 104 p.

[11] Azarenkov N.A., Pignastyi O.M., Khodusov V.D. Kinetic theory of oscillations in the parameters of the production line. Dopovidi Natsional'noï akademiï nauk Ukraïni [Reports of the National Academy of Sciences of Ukraine], 2014, no. 12, pp. 36-43.

[12] Pignastyi O.M. The network model of the multiple resources flow manufacturing line. Nauchnyy rezul'tat. Informatsionnye tekhnologii [Research Result. Information technologies], 2016, vol. 1, no. 2, pp. 31-45 (in Russ.). 
O.M. Pihnastyi, O.O. Parachnevych

[13] Demutskiy V.P., Pignasta V.S., Pignastyi O.M. Teoriya predpriyatiya: ustoychivost' funktsionirovaniya massovogo proizvodstva i prodvizheniya produktsii na rynok [Theory of the enterprise: stability of the mass production functioning and promotion of products to the market]. Kharkiv, KhNU Publ., 2003. 272 p.

[14] Pignastyi O.M. Analytical methods for designing technological trajectories of the object of labour in a phase space of states. Nauchnyy vestnik NGU [Scientific bulletin of National Mining University], 2017, no. 4, pp. 104-111.

[15] Pihnastyi O.M., Korsun R.O. The construction a kinetic equation of the production process. Avtomatizirovannye tekhnologii i proizvodstva [Automation of Technologies and Production], 2016, no. 1 (11), pp. 10-17.

[16] Pignastyi O.M. Engineering and production function of the enterprise with serial or mass production. Voprosy proyektirovaniya i proizvodstva konstruktsiy letatel'nykh apparatov, 2005, no. 42 (3), pp. 111-117 (in Russ.).

[17] Pihnastyi O.M. Statistical validity and derivation of balance equations for the two-level model of a production line. Skhidno-Evropejs'kij zhurnal peredovih tekhnologij [Eastern-European Journal of Enterprise Technologies], 2016, vol. 5, no. 4 (83), pp. 17-22.

[18] Demutskiy V.P., Pignasta V.S., Pignastyi O.M. Stochastic description of economicproduction systems with mass production. Dopovidi Natsional'noï akademï nauk Ukraïni [Reports of the National Academy of Sciences of Ukraine], 2005, no. 7, pp. 66-71.

[19] Moiseev N.N. Elementy teorii optimal'nykh system [Elements of the optimal systems theory]. Moscow, Nauka Publ., 1974. 526 p.

[20] Pignastyi O.M., Khodusov V.D. Model of conveyer with the regulable speed. Vestn. YuUrGU. Ser. Matem. modelirovanie i programmirovanie [Bulletin of the South Ural State University. Ser. "Mathematical Modelling, Programming \& Computer Software"], 2017, vol. 10, no. 4, pp. 64-77. DOI: $10.14529 / \mathrm{mmp} 170407$

[21] Armbruster D., Marthaler D., Ringhofer C., Kempf K., Jo T.-C. A continuum model for a reentrant factory. Operations Research, 2006, vol. 54, no. 5, pp. 933-950.

DOI: $10.1287 /$ opre.1060.0321

Pihnastyi O.M. - Dr. Sc. (Eng.), Professor of Department of Distributed Information Systems and Cloud Technologies, National Technical University "Kharkiv Polytechnic Institute" (Pushkinskaya 79-2, Kharkov, 61102 Ukraine).

Parachnevych O.O. - Engineer of Department of Distributed Information Systems and Cloud Technologies, National Technical University "Kharkiv Polytechnic Institute" (Pushkinskaya 79-2, Kharkov, 61102 Ukraine).

\section{Please cite this article as:}

Pihnastyi O.M., Parachnevych O.O. On the Formulation of the Problem of Optimal Control of Production Parameters using a Two-Level Model of the Production Process. Vestn. Mosk. Gos. Tekh. Univ. im. N.E. Baumana, Priborostr. [Herald of the Bauman Moscow State Tech. Univ., Instrum. Eng.], 2018, no. 3, pp. 83-90. DOI: 10.18698/0236-3933-2018-3-83-90 